\title{
迹政 Empowerment of Women: A Case Study of a Self Help Credit Program in Nithari Village, Noida, India
}

\author{
Shikha Kapoor ${ }^{1}$
}

\begin{abstract}
In modern times a nation cannot afford to have any of its citizens who are capable of economic development to be non-productive. However, the resource crunch, lack of skills and financial paucity leads to $75 \%$ people being unemployed. This can be elevated through interventions of Government by giving directions and purpose for their livelihood. Empowerment is the ability to gain power over oneself and take decisions over one's life. It boosts the confidence, self-esteem, wellbeing and control over one owns life. The study explores the influence, through focus group discussions and interviews, of self-help groups, which can contribute towards economic development and livelihood programs to make a difference in the life of citizens below the poverty line. The paper brings out the effectiveness of social mobilisation and economic development by presenting the cases and demonstrates how they are making a difference in society. It tries to analysis how SHG as a part of social innovation can be used for empowering women /girls through entrepreneurship alleviation. It also reveals its social and economic implications by women involvement in productive and financial contribution in the family hence addressing the importance of SHG's and its progressive development of women .New public policies can be designed to strengthen and pave the way for financing these SHG (Self Help Group). Corporates can be encouraged to adopt regions to support SHG as part of mandatory CSR (Corporate Social responsibility) activity as per Companies Act 2013 in India. This paper summarizes how selfhelp groups may promote awareness among the members if they are provided with sufficient opportunities for empowerment to combat poverty. Besides, involvement in SHG's has enabled members to voice their opinions on community affairs, and it has also helped in gaining freedom, self-confidence, self-identity to tackle problems and gaining power over decision making in the household.
\end{abstract}

JEL classification: G21, J16, M13.

Keywords: India, Women, Poverty alleviation, society, sustainable, empowerment, microfinance, SHG.

\footnotetext{
${ }^{1}$ Professor, Amity International Business School, Amity University, Noida, India
} 


\subsection{INTRODUCTION}

The Rig Veda and Upanishads talk about several women sages. The list of powerful women from India are Razia Sultan ,Jijabai, Laxmi Bai of Jhansi etc. As India progressed in $20^{\text {th }}$ and 21 st Century women took a big step in politics, business, performing arts, sports and administration.

The status of women in all countries of the world is important today . Different Five years plans have highlighted the welfare measures and advancement for women. The strategy adopted by The Ninth Five Year Plan (1997-2002) was Women's Component Plan (WCP), The process of organizing women into Self-Help Groups (SHGs), this was to provide an opportunity for articulating their needs contributing their perspectives to development .The Government of India declared the- year 2001 as “Women's Empowerment Year” to focus on a vision where women are equal partners like man. Later five year plans attempted to move beyond empowerment and recognize women as agents of sustained, rapid and more inclusive socio-economic growth and change.

In modern times, there is an increasing trend in women participation in all the pivotal roles. Role of women has become fast-paced in last two decades. They are creating new communities of diversity and integrity; they are trustworthy, employable and eager to take new challenges in their stride. Empowerment of women through gainful employment is a component as well as an instrument of development in any country.( Kabeer, Naila. 1999).The active participation and coming out of purdah system by Indian women in the entrepreneurial economy has stimulated innovation, wealth creation and prosperity. New challenges for women's equality are because of the globalization which has given women new positive self-identities outside the domestic chores. Female empowerment has become an instrument through which women can improve their own living conditions and that of their children. They are now becoming an income generating helping hand for their family. This changing status of women is due to growing industrialization, urbanization, spasmodic mobility and social legislation. Women are becoming professionals, contributing to the economy of the country, thus women entrepreneurs are on rise.

There are several women projects like SEWA, Shri Mahila Griha Udyog, Lijat Ppad, Project Shakti. There are successful women across various fields . There are Business women, pilots, engineers, astronauts, taxi drivers, armed forces, politicians, CEOs.

\subsection{LITERATURE REVIEW}

Women Empowerment means improvement / enhancement of economic, social , political and spiritual, power of Women, thus involves developing confidence in their own capacities.Women's economic empowerment is one of the contributing factors to achieving equality with men. But economically strengthening women is also a matter of advancing women's human rights. (ILO). Organising women in the thrift and credit services is the most effective method for empowering women ( World bank 1995, 2001/2002) World Conference on Women Rights (Vienna 93), International Conference for population and development held in Cairo 1994 and $4^{\text {th }}$ World conference on women issues held in Beijing in 1995 were the landmark and the largest platform discussion on women issues. In Cairo, for the first time, a separate chapter on women's equality and women empowerment was included in the plan of action ( POA) document. 
According to the Grant Thornton, International Business Report, "Women in Business" ,Indian women in senior positions in the workplace in the world has increased from $16 \%$ in 2016 to $17 \%$ in 2017 with India 17\%,UK 19\%, Russia 47\% Even after improvement of participation of women in workforce ,there is a gap in India to support or mentor women as per the business reports. Women are usually in the lower paid and lower position jobs and are in narrow range of occupations and sectors .(ILO,,World Employment social outlook , Trends 2018) According to ICPD Program of Action Para 4.4,Countries should act to empower women and to take steps to eliminate inequalities among men and women ... Issue of women's rights was raised by U.S. President Barack Obama on his visit to India in Jan 2015. "According to him for a successful nation , the women have to develop, this is one of the measures " (U.S. President Barack Obama delivers a speech at Siri Fort Auditorium in New Delhi January 27, 2015. REUTERS/Jim Bourg)

K M Zahidul Islam et al, (2011) empirically examined the technical, economic and allocative efficiency of agricultural microfinance borrowers and nonborrowers in rice farming in Bangladesh using Data Envelopment Analysis (DEA) of survey data obtained in 2009 .The SHGs have been recognized as a useful tool to help the poor and as an alternative mechanism to meet the urgent credit needs of poor through thrift (Thalavai Pillai \& Nadarajan, 2010).

Lucy, Ghosh, and Kujara (2008) in their study aimed at understanding the level of empowerment exhibited by women by participating in microcredit loan program. They identified how SHG's in women entrepreneur program demonstrated empowerment related to education, land and asset ownership . Improving the well beings of families, household nutrition and raising the aspirations for children education, Niels Hermes et al, (2007) has mainly concentrated on poverty reduction through improving education, health and infrastructure. Rosintan, Panjaitan Drioadisuryo and Cloud (1999) in their study included decision making, income, savings, business expenditure, household work and improved nutrition .

Galab and Chandrasekhar Rao (2003) Discusses in his paper about the strategy of government of Andhra Pradesh in alleviating poverty and providing space to women selfhelp program for womens empowerment. Manimekalai and Rajeswari (2002), conducted a study on "Grass roots entrepreneurship through Self Help Groups (SHGs)", the objective was to find out factors which have motivated women to become Self Help Group members are eventually entrepreneurs and analyze.It was observed apart from the women becoming independent, there was an improvement in the personal work, the community as a whole also. Anand (2002), in her discussion paper titled "Self Help Groups in empowering women; examined the performance of the selected SHGs and assessed the impact of micro credit programme on empowering women . According to Agarwal, Deepti (2001), women need to be viewed as an active participant for the progress Development and empowerment of women should be organized for their economic and wellbeing. Rosintan, Panjaitan Drioadisuryo and Cloud (1999) in their study included decision making, income, savings, business expenditure, household work and improved nutrition .

Studies related to credit requirement and credit supply in India have brought to light that there is a huge gap in them (Chandra, 1993). Shekle (2009) has found that mostly the investment and credit requirements form the basis around which the self help groups are formed in India. SHGs have emerged as a movement, and with the government help have been able to effectively help the needy women entrepreneurs of the society (Emerlson \& Moses, 2007). 
It was seen from the above research that improvement in the women economic and social condition needs effective access. Increase the women access to credit and increase their earning capability is the need of the hour . Organising women into groups improve their solidatity, strengthening socio economic empowerment. The time is to improve their confidence, self esteem and self worth for empowerment .

\subsection{EMPOWERING THROUGH SELF HELP GROUPS}

Economic empowerment means promoting gender equality and also providing resources in the hands of women and expanding their horizons and opportunities in various sectors of society. An increased economic role may lead to an increased status in gender roles, and a better position in the household and communities.

It consists of:

(1) 'Power within', helps and enables women to articulating one's own aspirations and strategies for change;

(2)'Power to', develop and enable women to achieve their aspirations by developing the necessary skills by accessing the required necessary resources

(3) 'Power with', enabling women to organize, achieve by examining and articulating collective interests for change; and

(4)'Power over', helping the women's aspirations and their ability

Social mobilization and collective agency are the two routes which are imperative for women empowerment identified by UNDP.

Indicators of empowerment:

(i) economic independence

(ii) making decisions in household and income earnings

(iii) mobility in the public

(iv) ownership of assets

(v) making purchases;

(vi) Freedom from domination and make own choices

(vii) Political awareness and participation in political action of various kinds;

\section{Social Approach measure for Empowerment:}

- Being Self-reliant and increase the women empowerment

- Inculcate them with confidence to work independently

\section{Economic Approach measures Empowerment:}

- promoting self-reliant people institutions

- creating an effective demand stream

- access for livelihood services

Five Year Strategy Plan (FYSP) (2011-2016) Plan approach was to help women alleviate dependency and help themselves through initiative like Self-Help Groups (SHG). The Twelfth Plan has identified the key development to empower women for economic empowerment, social and physical infrastructure, enabling legislations, women's participation in governance. Today's women are innovative and ambitious, who is mentoring opportunities at all levels of the jobs. 


\section{Empowering through Self Help Groups}

The origin of Self Help Groups (SHGs) is the brainchild of Grameen Bank of Bangladesh, founded by Prof. Mohammed Yunus in 1975, who tried out a new approach to rural credit in Bangladesh. Grameen gave loans without asking borrowers either to provide collateral or engage in paper work. In India, NABARD initiated SHGs in the year 1986-87 But the real effort was taken after 1991-92 from the linkage of SHGs with the banks A self-help group (SHG) is a voluntary group of members composed of 10-20 local women valuing personal interaction and mutual aid .SHG is to improve the standard of living for sustainable livelihoods. SHG are even called by Swayam Sahita Samuh. The approach is both social and economic empowerment. Most self-help groups are located in India they are usually illiterate.

But some can sign their names and some have a primary school education SHG's are voluntary associations of people formed for certain collective goals that could be social or economic or both. Meetings are held every week. This is to discuss the agenda of the disbursement of loans, collection of savings. A record is maintained about the savings, contributions by the educated member of the group and the facilitator is provided with an honorarium by the group. Small regular savings are done. Saving accounts are opened for each member. The interest is taken by the bank form the members and a limit of loan is there. It helps in entrepreneurship development, skill development and increases the income of the members also empowers women. (Rahman, 1999). Many companies are helping in innovative programs geared towards women self-empowerment initiated which include direction towards sustainable livelihood and micro-enterprise promotion where women from local villages join hands together. (Kapoor, 2015). In India NABARD had initiated in 198687, but the real effort came with linkage of SHG 's with the banks

There are 3 models of credit linkages of SHGs with banks that exist in India :

\section{Model I: SHGs formed and financed by Banks}

\section{Model II: SHGs formed by NGO 's and other agencies as finacial intermediaries.}

\section{Model III: SHGs formed by banks, using NGO's and other agencies as financial intermediaries}

\section{Identification of Inherent Skills of Rural Women in India}

The skill identified for development includes making handcrafted gift items, products made from glass, cane and bamboo .Embroidery, stitching, making pickle, sauce, jam, jelly, squash, agarbatti, chalk , candles, phenyl, soap preparation, carpet making, and retailing , making doormats, coir products, rope and toys. are some of the skills identified.

\section{Corporates as part of the CSR activities are indulging in the upliftment of women as their core area of women empowerment .}

Tata as part of their continual efforts for women upliftment, to strengthen the role of women as a partnership .Tata through CSR arm has helped in the formation of more than 200 Self Help Groups (SHGs) in the State and provided them sustainable livelihood opportunities. Out of which 90 per cent of these SHGs are run exclusively by women, - it has also provided a livelihood to 3,000 households. 
ICICI Bank through self-help groups is supporting one million women to become self-reliant, these aim at empowering less privileged women . ICICI Bank in 2014 has provided loans in seven states to seven states. They have helped about 2 million beneficiaries by the end of FY15.

The bank runs the programme through a dedicated pool of 550 employees who look after servicing of SHGs spread across Maharashtra, Gujarat, Madhya Pradesh, Rajasthan, Tamil Nadu, Karnataka and Kerala

Hindustan Lever Limited (HUL) started Project Shakti in Andhra Pradesh in 2000 and started 50 SHGs in 50 villages and around 2000 inhabitants were the participants of the program .The products are sold in 100,000 villages and generate half of its business in India. Training is given to the women in sales, commercial knowledge and bookkeeping techniques to help them become micro entrepreneurs. Project Shakti is present in 15 states. By 2010 500,000 villages were covered by 100,000 shakti entrepreneurs, serving 500 million customers.

Jindal Steel and Power Ltd (JSPL) started as self-help group 'Sakhi 'as part of its Corporate Social Responsibility has started a brand name of "Ssodashi", they are preparing the low-cost sterilised napkins .

Oriflame has encouraged Entrepreneurial ship. They started a self-help group (SHG) Hand in hand and Microfinance Projects women's literacy programmes. The goal is to empower poor rural women and helping them to become entrepreneurs and thus helping hand to the families.

ITC women's Economic program mobilizes poor women to form micro-credit self-help group members make compulsory monthly contributions to create an initial corpus which is built upon with seed money from ITC, commencing from 2000 the program supports 1,682 operational SHGs with 20,250 members and cumulative savings of 3.52 crores . 31,034 women are self employed, while 7,731 women are employed in the micro enterprise. They have started agarbatti production .

Lavasa Corporation Ltd (LCL) is working on socio economic development for women through SHG's and upgrading the skills by capacity building workshops under its Corporate Social Responsibility. Focus is on empowering women by facilitating them on financial planning, linkage development, business development and leadership development. It continues to encourage women to have self-confidence and hold their heads high.

\subsection{THE PROJECT UNDERTAKEN TO STUDY ON SELF HELP FOR WOMEN EMPOWERMENT}

\subsection{NEED FOR THE STUDY}

To promote sustainable livelihoods for poor, especially womenfolk through the provision of financial and technical support in an integrated manner. SHGs progressively enhances the women to become self-reliant, self-dependent and provide a forum for dealing the socioeconomic problems. 


\subsection{OBJECTIVES:}

To conduct an impact assessment of self-help groups for women empowerment as part of

CSR activities by NHPC and identify the effectiveness of the self-help program .

The present study attempted to assess the Effect of Self Help Groups (SHGs) for women empowerment in Villages of Noida as part of the CSR study of NHPC . Model 2 of the credit linkages of SHG 's with banks that exist in India was taken

\subsection{METHODOLOGY:}

The methodology used to conduct of this study on the socio-economic impact on women was done by collecting primary data through surveys, interviews and focus groups.

The impact assessment took place in the following phases:

\section{PHASE1: Actual Survey through}

- Questionnaire1: Surveying

To identify the course of action adopted towards the social cause (Arrangement of loans, type of training, duration of training, etc.).

- Questionnaire2: Surveying the women who were working to measure the efficacy

To learn about the effectiveness of the steps taken (Benefits to women, earning, skills learnt, etc.).

\section{PHASE2: Analysis of the data collected}

Analyzing the primary data gathered using various statistical tools like mean, bar graphs, and histograms.

\section{PHASE3: Report Preparation}

A detailed preparation of the findings and conclusion in the form of a report.

\section{PHASE4: Recommendations}

Suggestions by the consultant/ Professional after a practical understanding of the situation

\subsection{METHODOLOGY}

The village of Nithari (the village under study) is located in Noida Sector -31, District Gautam Budh Nagar. There are 40,000 people staying in the village. There are concrete houses in the village. It is an urban and modern village with basic amenities. The village has a Garam Panchayat, with elected members (20 members) and a woman pradhan who is a graduate from Delhi University. 


\subsection{Choice of the study area}

The initial survey was done by the staff of the Janhit foundation, the NGO working for the sustainable livelihood for the womens workforce in rural areas. Nithari village was purposively chosen for the present study as there was no economic activities involved among the people of the village.

\subsection{Selection of the respondents}

The study included both primary and secondary data. Primary data was taken from the people of the village through pre-designed questionnaire from 500 households which culminated to 16 SHG groups and 145 women in economic activity. Average membership of the SHG respondents has 10 members and 2 groups out of 16 has 12 members each .

\section{Working Process:}

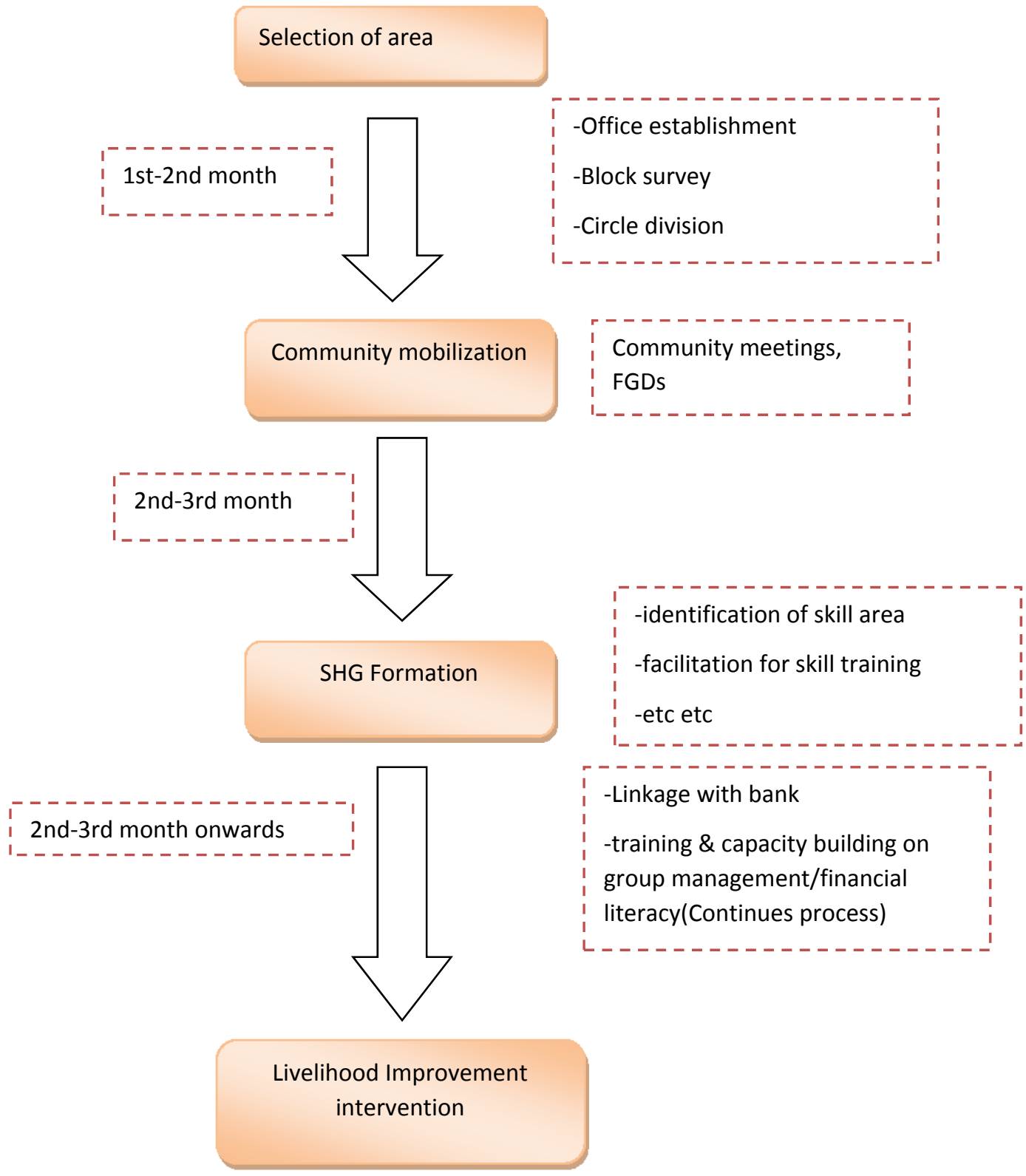




\subsection{WORK STARTEGY}

A whole block in the village was divided into two federations, each having four clusters Each cluster was comprised of 10-12 villagers who were geographically connected to each other and looked after by a 'Community Organizer'. Janhit (NGO) initiated its intervention in NOIDA with support from the National Hydro Power Corporation .

\section{Table 1:- Distribution of the women in SHG formation in Noida}

\begin{tabular}{|l|l|c|}
\hline Village & District & Total Number of SHGs \\
\hline Nithari & Gautam Budh Nagar & 16 (Functional Group) \\
\hline Mohra & Gautam Budh Nagar & 2 (Only group formed) formation \\
\hline Barola & Gautam Budh Nagar & 4 (Only group formed) \\
\hline Sadarpur & Gautam Budh Nagar & - \\
\hline Grand Total & & 22 \\
\hline
\end{tabular}

As per the survey of the Village Nithari, the women were divided into small groups called self-help groups. Two separate questionnaires were conducted to obtain general information on the SHG.The questionnaire 2 was used to collect specific information from each member of the women SHGs. Secondary Data related to the savings, loans were taken from the bank. Focus group discussions and panchayat meetings were held.

\subsection{MAJOR FINDINGS}

\section{SOCIO - ECONOMIC PROFILE :}

The sample consisted of 145 women from 16 SHGs operating in village in sector 31 called Nithari village, Tehsil Bisrakh in District Gautam Budh Nagar .There were average of 10-12 women in each SHG. The lowest average membership of about 10 and the highest average membership of 12.The average size of families were five or more members.. The monthly savings ranged from Rs 100 to 500 per member. (RFA). The total amount of Revolving Fund Assistance received by the women SHGs in Nithari Village was Rs. 3,00,000. The outstanding loan for all the 8 group in total was Rs 2, 32,900. The 21 women of 8 SHGs Rs.10,000 average from the bank. The Shivalic Merchantile Cooperative Bank (SMCB) provided Rs.3,00,000 under microcredit at the rate of $18 \%$ interest per annum (floating). 16 SHGs (60\%) were engaged in economic activities. Among the 500 households surveyed, most of the women were engaged the ongoing economic activities and some took up new economic activities.

Overall, 145 women are involved in economic activities. $18 \%$ interest was charged by the bank as part of the microcredit given to the women SHGs. The interest rate on the loan amount was $2 \%$ per month for inter circulation of loan, and this went for the SHG's savings. In later stages the interest savings was provided as a dividend to members .In this study also, almost all the SHGs reported $100 \%$ repayment. The circle coordinator of the NGO, Treasurer and 
President of the SHG deposited the monthly loan in the bank. For Rs 10,000 loan taken by SHG deposit was Rs1000/- monthly and Rs 15,000 loan taken by the SHG deposit Rs 1500/- . SHGs in Nithari village showed that almost half the loan was used in improvement of their occupation, for buying buffalo, vegetable trolley for sale, small shop establishment near their house. Among the 21 members, 15\% utilized of the money was used in loan payment, house construction, about $10 \%$ on education, $75 \%$ on economic activity. The SHG movement has created awareness among the women. These women were involved in the elections in Noida. About $30 \%$ of the women SHG's members participated in Village meetings. The women pradhan utilized most of the women in village activities for awareness of health and sanitation and other activities e.g camps for health AHM (Associated Nurse Midwives). The women also participated in brainstorming session for a better future in the village. Health related issues for women and children were also discussed in the village. The women were between the age group 18 to 50 yrs. About $85 \%$ of the women belonged to the age group 18 to 40 years and the rest $15 \%$ are in the age group of $40-50$ yrs. Out of 145 members, about 97.93(142) were married, $0.68 \%$ were widows (1), and $1.37 \%$ (2) were unmarried women. (Table.3). About $60.33 \%$ of the respondents had primary level education, about $15.17 \%$ had high school education. Further, only about $10 \%$ remained illiterate (Table 4).

Table 2 Age group of the SHG women

\begin{tabular}{|l|c|c|}
\hline Age & No & \% \\
\hline $18-30$ & 51 & 35.17 \\
\hline $30-40$ & 72 & 49.65 \\
\hline $40-50$ & 22 & 15.17 \\
\hline Total & 145 & 100.0 \\
\hline
\end{tabular}

Table 3 Marital status

\begin{tabular}{|l|c|c|}
\hline Women status & No & \% \\
\hline Unmarried & 2 & 1.37 \\
\hline Married & 142362 & 97.93 \\
\hline Widow & 1 & 0.68 \\
\hline Divorcee & & \\
\hline Destitute & & \\
\hline Total & 145725 & 100.0 \\
\hline
\end{tabular}

Table 4 Educational status of the women

\begin{tabular}{|l|c|c|}
\hline Education level & Number & \% \\
\hline Primary( Upto 8 Class) & 113 & 60.33 \\
\hline High school & 22 & 15.17 \\
\hline Illiterate & 10 & 14.5 \\
\hline Total & 145 & 100.0 \\
\hline
\end{tabular}

\section{Occupational status of the respondents}

The women of the village were housewives. After the SHG formation among the 145 sample women, only 96 women (66.20\%) did activities like washing, cooking, cleaning 
of household in the nearby colony, etc., and 45 women $(31.03 \%)$ were housewives and 4 women 2.75\% engaged in new economic activities like defusing bulbs activity and stitching activity, etc., after enrolling themselves in SHGs, 100 women were involved in economic activities directly . 45 of them had improved on the education , awareness, saving participation. (Table.5).

Table 5 Economic Activities of the women

\begin{tabular}{|l|c|c|c|c|}
\hline Economic Activities & \multicolumn{2}{|c|}{$\begin{array}{c}\text { Before formation of } \\
\text { SHGs }\end{array}$} & \multicolumn{2}{c|}{$\begin{array}{c}\text { After formation of } \\
\text { SHGs }\end{array}$} \\
\hline & No & \% & No & $\%$ \\
\hline Traditional economic activities & 30 & 20.68 & 96 & 66.20 \\
\hline New economic activities & 0 & 0 & 4 & 2.75 \\
\hline
\end{tabular}

The family consisted of 4-5 members and had one bread earner. Some women were working in nearby houses as maids for washing and cleaning. By forming SHG and the microcredit programme, , the women annual income considerably increased. The annual income were classified into six categories, as mentioned in Table .6. It was seen that majority of the women earnings were in the bracket of 25,000-40,000 per annum. Table.6).

Table 6 Annual income of the women

\begin{tabular}{|l|c|c|}
\hline $\begin{array}{c}\text { Annual Income level } \\
\text { (Amount in Rs per annum ) }\end{array}$ & $\begin{array}{c}\text { Before formation of } \\
\text { SHGs }\end{array}$ & $\begin{array}{c}\text { After formation of } \\
\text { SHGs }\end{array}$ \\
\hline & & \\
\hline Less than Rs 15000 & 6 & 2 \\
\hline $15001-25000$ & 22 & 10 \\
\hline $250001-40,000$ & 47 & 30 \\
\hline $40,000-60,000$ & 45 & 55 \\
\hline $60,000-80,000$ & 20 & 32 \\
\hline Rs 80,000-and above & 5 & 16 \\
\hline
\end{tabular}

Mostly people live in their own concrete houses and $20 \%$ occupied rented houses. Most women had electricity and used the Public Distribution System (PDS), and had access to LPG and possessed communication facilities. There are govt schools in the locality .

\section{SELF HELP GROUP Formation and Saving}

\section{Cumulative saving by Self Help Groups}

\begin{tabular}{|l|l|}
\hline Apr'18 & 1.55 Lacs \\
June'18 & 2.10 Lacs \\
\hline
\end{tabular}

As per cumulative saving done by SHG's in April 2012 had been increased to 2.10 Lacs in June 2012. The increment itself showed the improvement and success of SHG's 


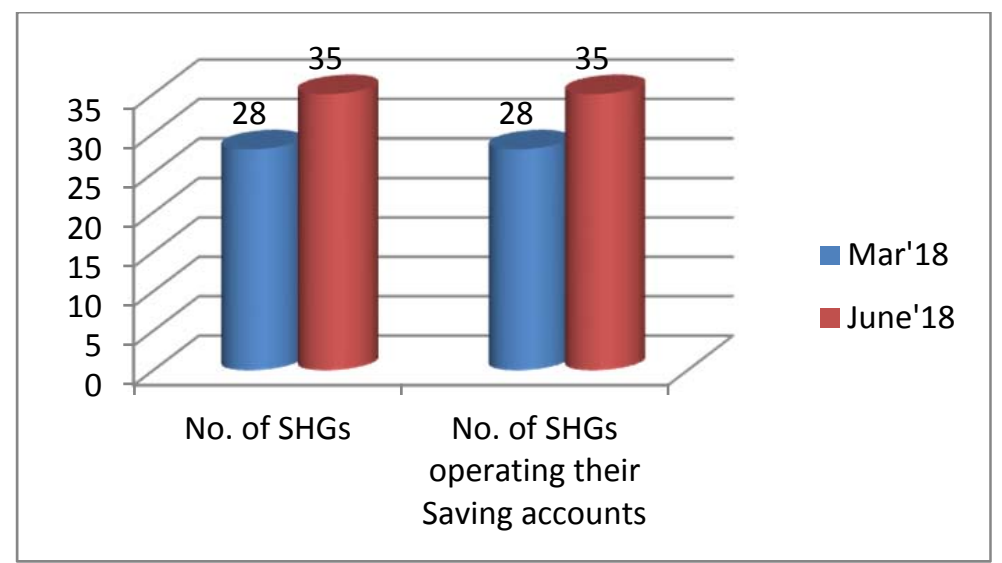

Fig 1: SHG and their saving accounts

The study has brought to light that the number of SHGs in March 2018 and June 2018 has increased 28 lakhs to 35 lakhs with the operating saving accounts.

\section{Capacity building and nurturing of SHGs:}

The SHG had group meetings fortnightly and informal training session on finance, group formation, teams work, leadership skills and child wellbeing, health and hygiene, sanitation etc were conducted. 40 sessions were organised in 3 months. Training sessions on 'accounting and book keeping' and 'leadership skills' were also conducted .

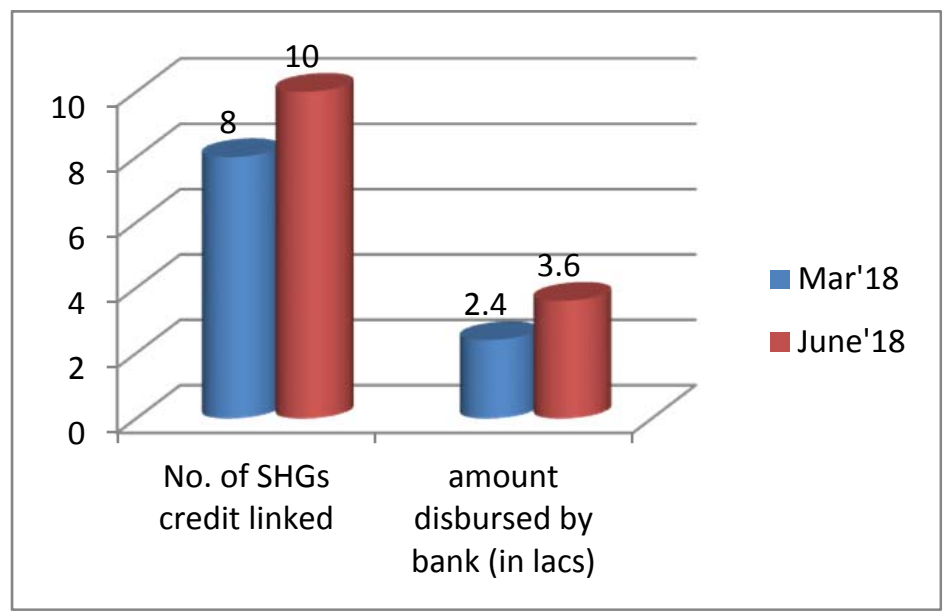

Fig 2: Credit facilitation from bank

The Bank disbursed INR 3.60 Lacs to SHG for utilization for economic activities and different purposes and only 10 SHG got linked to the banks who passes the grading criteria and scores . 


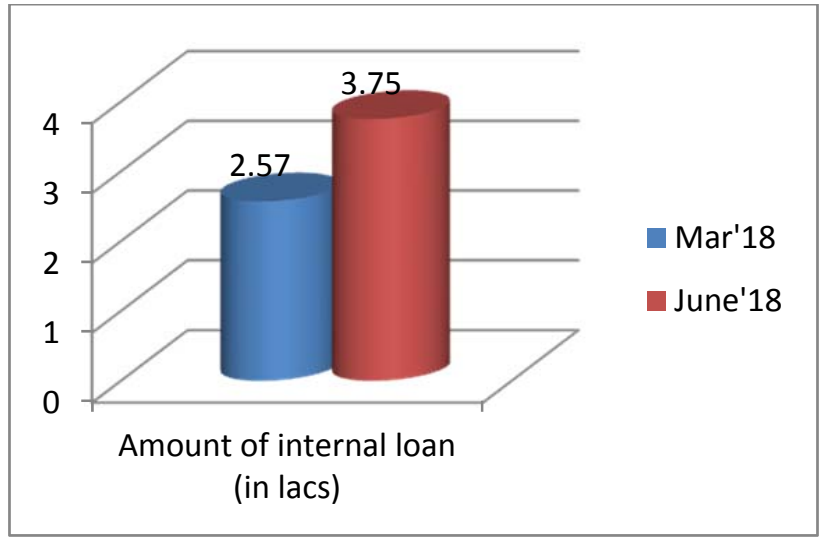

Fig 3: Internal loaning of Self help Groups

Out of total 35 SHGs formed and facilitated, 28 SHG's started practicing internal loaning out of which 10 SHGs.

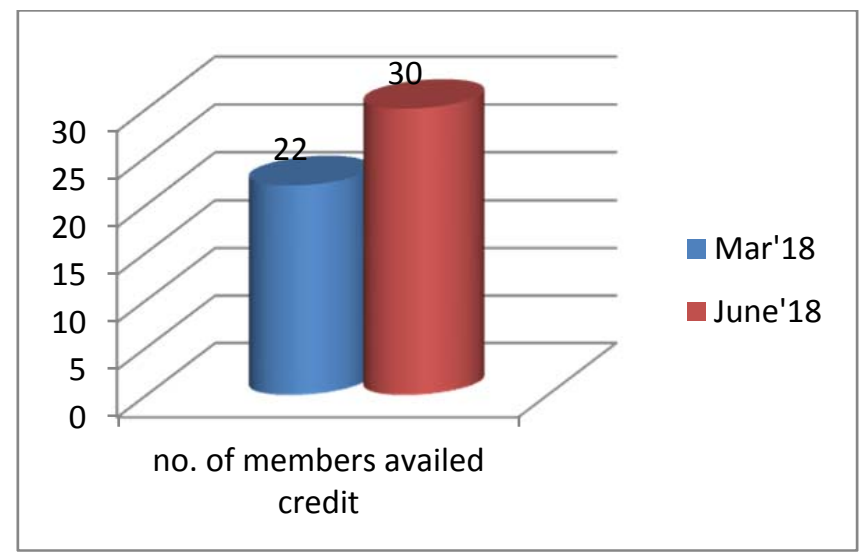

As we can see from the above graph that no. of members availing credit has also been increased from 22 in Apr '18 to 30 in Jun '18

\section{LIVELIHOOD IMPROVEMENT:}

Women were encouraged to learn a skill and potential entrepreneurs were tapped for effectively enterprise development services. 


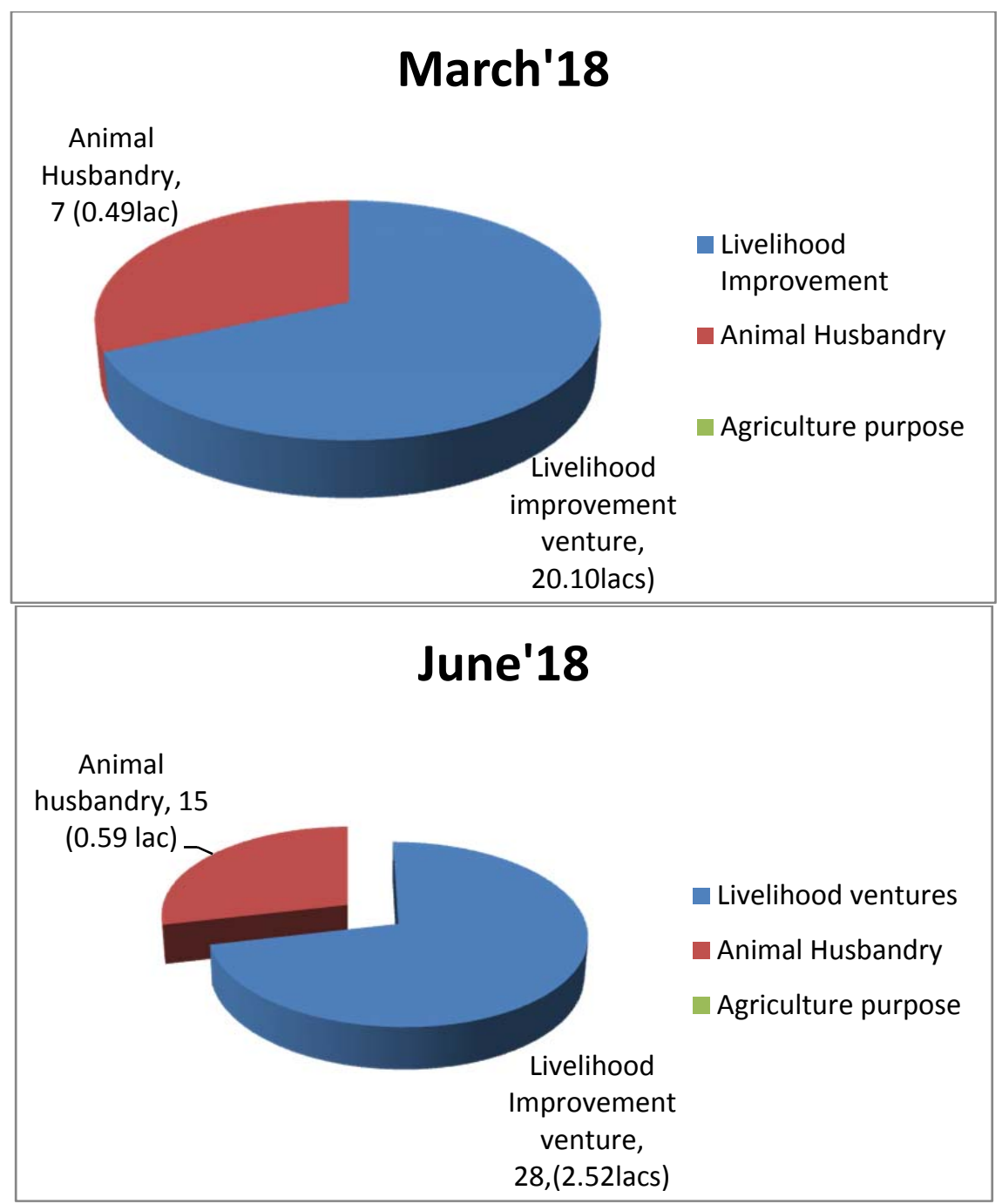

Figures: purpose of loan, no. of members availed, \& amount

Within a 4 months of the time of study, it was found that the entrepreneurial skills were increased to diverse business activity. The number of women entrepreneurs doing animal husbandry activity was increased from 7 in March to 15 in June. The investment amount under this business activity also rose from 0.49 lakhs to 0.59 lakhs from March to June 2018. The SHGs of the Nithari area showed no trend of rising under the agriculture sector in this time because these ladies and their families do not own land and live mostly in rented houses. But other livelihood improvement ventures related to health and education and asset creations showed a rise. They increased from 20 to 28 in number. The Investment level in this sector rose from 1lakh to 2.52 lakhs .

Investment towards Health \& Education and Asset creation:

\begin{tabular}{|c|c|c|c|c|}
\hline & \multicolumn{2}{|c|}{ Mar '18 } & \multicolumn{2}{c|}{ June '18 } \\
\hline & $\begin{array}{c}\text { No. of } \\
\text { loans }\end{array}$ & Amount & $\begin{array}{c}\text { No. of } \\
\text { loans }\end{array}$ & Amount \\
\hline Health \& Education & 4 & 0.05 Lacs & 5 & 0.38lacs \\
\hline Asset creation & 2 & 0.02Lacs & 4 & 0.40Lacs \\
\hline Money lenders repayment & 2 & 0.25lacs & 3 & 0.30lacs \\
\hline
\end{tabular}


The number of loans and amount for Health and Education rose from 4 to 5 in number and .05 lakhs to .38 lakhs respectively. Similarly the number of loans and amount Asset creation rose from 2 to 4 in number and .02 lakhs to .40 lakhs respectively. The number of loans and amount for money lenders repayment rose from 2 to 3 in number and .25 lakhs to 0.30 lakhs respectively.

\section{Overall Progress under SHG-Bank Linkage in India in past yrs (SHG Savings with Banks as on 31March 2016 -18)}

\begin{tabular}{|l|l|l|l|l|l|l|}
\hline & $\begin{array}{l}\text { No. of } \\
\text { SHGs } \\
\text { 2015-16) }\end{array}$ & $\begin{array}{l}\text { Saving } \\
\text { Amount } \\
(2015-16)\end{array}$ & $\begin{array}{l}\text { No. of } \\
\text { SHGs } \\
\text { 2016-17) }\end{array}$ & $\begin{array}{l}\text { Saving } \\
\text { Amount } \\
(2016-17)\end{array}$ & $\begin{array}{l}\text { No. of } \\
\text { SHGs } \\
\text { 2017-18) }\end{array}$ & $\begin{array}{l}\text { Saving Amount } \\
\text { 2017-18) }\end{array}$ \\
\hline $\begin{array}{l}\text { Total } \\
\text { SHGs }\end{array}$ & 7903002 & 1369139.01 & 8576875 & 1611422.64 & 8744437 & 1959211.52 \\
\hline $\begin{array}{l}\text { All } \\
\text { Women } \\
\text { SHGs }\end{array}$ & 6763457 & 1203578.18 & 7321608 & 1428342.27 & 7390097 & 1749786.04 \\
\hline
\end{tabular}

\section{Source : NABARD report on status of microfinance 2015-16, 2016-17, 2017-18}

The upward increase of the SHG since 2012 ( it was the initial years of SHG's in India )and the status now. There is a progressive increase. This is the study of NABARD data . But corporates are also helping SHG 's as part of CSR projects as given above .The SHG - Bank Linkage in India has been increasing since 2015 as is visible from the above table.

In $2015-16$, the number of SHGs which came under the umbrella of NABARD were 7903002 . These rose to 8576875 in the year 2016-17 and in 2017-18 the figure rose to 8744437 . This clearly shows the rising trust of SHGs in the banking systems.

Analysing the position of the Woman SHGs for the same period, it was seen that they followed the same rising trend. From 6763457 in 2015 -16 to 7321608 in 2016-17 and to 7390097 in 2017-18.

\section{NABARD's Strategic Focus on SHG-BLP (2013-18)}

- Promotion of Women SHGs in every rural household in the identified districts within the next two years and linked with banks and Convergence with Government Programmes like National Rural Livelihood Mission (NRLM) to maximise benefits to the SHG members.

On $25^{\text {th }}$ Aug 2017 as per the government's revised guidelines for 2016-17,the Reserve Bank had asked the banks to provide loans to women self-help groups (SHGs) at 7 per cent per annum,"All women SHGs will be eligible for interest subvention on credit up to Rs 3 lakh at 7 per cent per annum (under Deendayal Antyodaya Yojana-National Rural Livelihoods Mission Statement) Economic Times. 


\subsection{IMPACT TO BENEFICIARIES BY SHGS OF THE STUDY IN NOIDA}

Self-help groups have helped women in multidimensional spheres. They have raised their monthly income through their various economic activities. The self -sufficiency attainment took time but certainly helped in the development of women in terms of their social, economic and political growth. The empowered status was felt by the decision making trends taken by the women in relation to savings. The SHGs have also changed the women's attitudes for better living, a greater participation in family decision making, access to financial support and has strengthened their husband's occupation and increased their purchasing power. Awareness about family health and nutrition has improved. The women were more aware about the legal marriage age for girls, remarriage, child marriage, dowry, and are active in their participation in outdoor activities, and social and national functions.

There was significant economic, social, health, education, knowledge and political impact of SHGs on the sample women respondents. Their empowerment levels increase was significant during post-SHG situation as compared to their pre SHG situation. The group activity conducted as part of SHGs had influenced the women towards a richer, more peaceful, productive and purposeful life. There was a change in their attitude. The SHG members have also played an effective role in making other women aware in the area of womanhood, emancipation and empowerment. This has brought about a social change from the conventional stereotype women to more independent, emancipated women. These women achieve self-reliance, increased empowerment, and they are inculcated with confidence to work independently. It was observed that domestic violence in the family came down considerably in the post-SHG situation. Improved mobility in the group, seeing the economic growth of women, other women of the village wanted to join the SHG. Social mobility is imperative for women's emancipation. It was concluded that the SHG programmer impacted the social empowerment of sample SHG respondents in a significant way. There was improvement in certain skills also, improvement in control over resources, increase in credit worthiness, increase in self-confidence, freedom from money lenders, improvement in banking habits, increase in access to markets, increase in mobility, improvement in productive skills, improvement in communication skills, increase in bargaining power, improvement in marketing skills..Formation of SHG has created opportunities to women for income earning activities. SHG Program has been taken as a resource mobilization support for women since self-help approach gives a sense of achieving collective strength .SHG provided motivation for building up capacities in part of their members through providing capacity building process. Change in social 'Status' and 'Role' it was seen that there is an increase in participation in outdoor activities, participation in decisions. Positive change in the general attititude and behaviour of the husbands and other family members towards the fisherwomen. Social awareness among respondents were there pertaining to awareness of social customs (such as Dowry, Remarriage, child marriage, marriage of girls under 18 years, etc.).

Awareness regarding rights among respondents (Social, legal, political) Social status of the SHG members showed increased willingness to participate in outdoor activities. They were also involved in SHG activities. Membership attendance increased in participation of weekly meetings and participation in PRI activities. Most of the SHG members participated in weekly meetings where family problems regarding finance, health, children education, economic activities and women empowerment and so on are also discussed. These women were led by a woman coordinator from the village 
itself. Suggestions are also provided to them by women SHGs federation members and the Pradhan. Some of the members faced the problem of husband's misbehavior (towards wives). In that case, animator or federation members got involved in the problem and provided. counseling to them to help them solve their family problems. Family income increased because the SHG loan amount was invested for improving husband's occupation. In case of women SHG members the loan amount was utilized for purchase of animals, repair of house, repaying of loan of $5 \%$ per month. Social awareness regarding child marriage, child labour, correct marriage age, family health care and children education had increased. Personal development, self confidence also increased among the women after they enrolled themselves in the SHGs.The very status of being an SHG member had provided social status and self esteem which are hall marks of women with emancipation and empowerment.

The impacts of the microcredit program are many encompassing the various spheres such as cultural, socio-economic and political sectors. Economic Impact had a major role in womens development and raising their self esteem. There was an increase in the monthly income of the respondents through their various economic activities,Increase in annual household income is clearly demonstrated. A rise in expenditure incurred on various consumption needs is evident, mainly on food, health and education. The impact on health was also seen. Awareness of treatment seeking behaviour during ill health. Besides availing themselves of microcredit in banks, the members are also exposed to various awareness campaigns and multipurpose activities such as educational, economic, vocational and health activities which contributed to improving their overall awareness. Compulsory savings helped in building assets, clearing loans, demonstrate the cash flow and saving practices Minimum of Rs 100 per month is the compulsory savings.Voluntary savings services are provided to both borrowers and non-borrowers who can deposit or withdraw according to their needs.

The study covered 16 women SHGs in the district of Noida, Nithari village. These SHG were in the name of the coordinators Vaishnav, Durga, Om Sai, Laxmi, Siddhi, Radha, Sai and so forth. Talking to the various SHG coordinators, it was found that the following reasons for the success of womens SHGs in the villages wee mentioned:. As per Vaishnav, close interaction among the members. Unity and collective efforts in their aims (or) goals helped to improve the self confidence, Financial independence. There is a change in the personality of the women. Earlier they were closed and not open to new ideas. Now the attitude has changed for better living; Now they need not ask their husband for small things. They can buy small items for their children also. They participate in family decision making. Think about their childrens health and education there is more community participation, the purchasing power of these women has increased. They now like to participate in community gatherings, they spend on food, clothing, furniture, improvement of houses facilities. Women have become more articulate when they take an active part in all economic, political and social activities. The above reasons are contributed to the success of SHGs in the villages.

Entrepreneurs Development Programmes (EDP) should be provided by the Government. It remains more in theory than in practice for many reasons. Due to marketing problems, the SHG members have not attained self-sufficiency level in ntrepreneurship activities catalyzing these developments and contribute to their social, economical and political activities. These are the main problems faced by the SHG members in the study area. Now the NGOs has to promote to act as a bridge between the members and initiate 
a skill development program for SHG in Nithari Village. The study found that microfinance had indeed contributed to the overall socio-economic empowerment of the women apart from improving their livelihood conditions besides providing an opportunity to the banks to serve the 'unreached' Policies should be made for sustainability SHGs as motivation of members, new direction, progressive growth is important

\subsection{CONSTRAINTS FOR SHGS}

SHGs members were local women who were not exposed to the outside world and they had apprehensiveness about breaking social customs, little economic support, low levels of education and low levels of input into decision making in the household .The cooperative body officials were also not very supportive. There was poor monitoring and technical guidance and at times non-cooperation between family members which were initial stumbling block in their socio- economic empowerment. Entrepreneurship has made them more self-sufficient but the techno-economic skill needs to be continuously up graded to allow for sustainable development.

\subsection{CONCLUSION}

SHG's are a powerful instrument to help women uplift themselves in their social and economic status. They have to some extent helped to empower the women for small entrepreneurship in India. Further, it has encouraged women to save money after using it for domestic needs and to support their families. Aided by microcredit, women are running catering units, canteens, cooking for schools, supplying home-cooked food, doing tailoring and so on. The self-help group is increasingly promoted as a developmental policy worldwide, which has percolated in India as well. Capacity building is the mainstream language which the world bank uses when empowerment is associated with bottom up alternative resources. Women have realized that they have an important role to play in their family and in society and are confident of achieving their goals for their families by making important decisions. Over the years, highly successful women are seen in politics, academics, business, administration and media, and they have proved themselves and showed leadership in the changing structure of the economic, political-cultural, social, and legal environment. The current need is a well-designed strategy including a more transformative agenda and radical thinking about current priorities. Women's organizations all over the world have been advocating and demonstrating alternative approaches. A change can be brought about by changing societal attitudes of both men and women. Thinking about cultural aspects affecting women; strengthening the legal system aiming at the elimination of all forms of violence against women and girl children. Positive economic and social policies for the development of women can help in realizing our full potential. Decision making is the major turning point for social, political and economic emancipation for women. Positive approaches to economic, support from the government, family members and cultural migration will empower women to be exposed to better prospects at the international level. Equality between genders will have a deep-rooted and positive effect on women's empowerment in the socio-economic aspect. Information and communication technology have improved the access of women to microcredit, employment opportunities and information in general. Women Entrepreneurship is still a major hurdle for the women as it is more of a male-dominated field .

The "check the box" attitude towards CSR of some corporates will not work and businesses will have to be made responsible for contributing to sustainability. The "need of the hour" is nurturing support to women from all sectors i.e, family, socia , economic, government, 
corporates, and private agencies. Adequate training in entrepreneurship activities and skill development will definitely help women to lift themselves and their surroundings. Patience, a positive attitude and self-development for self-worth is needed for empowerment.

\section{References}

Abraham, A. (1991). Case Studies from the Women's Centre, Bombay, in Maitreyi Krishna Raj (ed), Women and Violence. A Country Report. (Bombay, UNESCO), 60-65.

Bhalla, N. (2015). Nations will only succeed if women are successful. Retrieved on $17^{\text {th }}$ Jan 19 from http://in.reuters.com/article/india-obama-women/nations-will-only-succeed-ifwomen-are-successful-obama-tells-india-idINKBN0L01H620150127

Economics Times (25 ${ }^{\text {th }}$ August 2017), Provide Loans to Women SHGs at 7\%: RBI to Banks.

Five Year Strategic Plan (2011-2016). Towards a New Dawn, Ministry of Women and Child Development Government of India. Retrieved from https://wcd.nic.in/sites/default/files/MWCD_Strategic_Plan_10-02-2011.pdf

Galab, S., \& Rao, N. C. (2003). Women Self-Help Groups, Poverty Alleviation and Empowerment. Economic and Poliltcal Weekly, 38(12-13), 1274-1283.

Grant Thornton International Business Report (March 2017 ). Women in Business - New Perspectives on Risks and Rewards. Retrieved on $15^{\text {th }}$ Jan 2019 from https://www.grantthornton.global/globalassets/1.-member-firms/global/insights/articlepdfs/2017/grant-thornton_women-in-business_2017-report.pdf

Hermes, N., \& Lensink, R. (2007). Impact of Microfinance: A Critical Survey. Economic and Political Weekly, 42(6), 462-465.

International Labour Organization. (1998). Women in the informal sector and their access to microfinance. Retrieved from http://www.ilo.org/public/english/employment/ent/papers/women.htm. Paper presented by ILO for the Inter-Parliamentary Union (IPU) Annual Conference, Windhoek, Namibia, 2-11 April, 1998.

Islam, K. M. Z., Backman, S., \& Sumelius, J. (2011). Technical, Economic and Allocative Efficiency of Microfinance Borrowers and NonBorrowers: Evidence from Peasant Farming in Bangladesh. European Journal of Social Sciences, 18(3), 361-377.

Kabeer, N. (1999). Resources, Agency, Achievements: Reflections on the Measurement of Women's Empowerment. Development and Change, 30(3), 435-464. https://doi.org/10.1111/1467-7660.00125

Kapoor, S. (2015). Human Resource Management, Text and Cases. Taxmann Publications. 
Kurian, D. A., \& Kapoor, S. ( 2015). Evolution of corporate social responsibility. International Journal of Research in Commerce, Economics \& Management, 5(5), 2127.

Lawania, B., \& Kapoor, S. ( 2016). Concept and practice of strategic corporate social responsibility: special reference to CSR in ITC limited. American International Journal of Research in Humanities, Arts and Social Sciences, 1(14), 83-87.

Lucy, D. M., Ghosh, J., \& Kuwaja, E. (2008). Empowering Women’s Leadership: A case study of Bangladeshi Microcredit Business, Society for Advancement of Management, 2008 International Business Conference, “Innovation” (2008)

Available at: http://works.bepress.com/denise_lucy/21/

Manimekalai, N., \& Rajeswari, G. (2002). Grassroots entrepreneurship through self help groups (SHGs). SEDMI Journal, 29(2).

NABARD. Status of Microfinance in India 2016-17 Retrieved on 20Jan 2019 www.nabard.org/auth/writereaddata/tender/1307174808Status\%20of\%20Microfinance \%20in\%20India\%202016-17.pdf

Rahman, A. (1999). Micro-credit initiatives for equitable and sustainable development : Who pays? World Development, 27(1), 67-82 https://doi.org/10.1016/S0305-750X(98)00105$\underline{3}$

Rosintan D. M., Drioadisuryo, P., \& Cloud, K .(1999). Gender, self-employment and microcredit programs: An Indonesian case study. Quarterly Review of Economics and Finance, 39, 769 https://doi.org/10.1016/S1062-9769(99)00028-9 